\title{
STRATEGIC MANAGEMENT AND PERFORMANCE DRIVERS
}

\author{
[Strategický management a hybné síly výkonnosti] \\ Žaneta Rylková ${ }^{1}$, Monika Chobotová ${ }^{2}$ \\ ${ }^{1}$ Silesian University in Opava, School of Business Administration in Karvina, Univerzitní nám. 1934/3,73340 \\ Karviná, Czech Republic \\ Email:rylkova@opf.slu.cz \\ ${ }^{2}$ Silesian University in Opava, School of Business Administration in Karvina, Univerzitní nám. 1934/3, 73340 \\ Karviná, Czech Republic \\ Email:chobotova@opf.slu.cz
}

\begin{abstract}
In the current global competition, companies want to gain competitiveness and to improve their competitive advantages. Strategic management has evolved to help organizations to operate successfully in competitive environment. Strategic management is an organized development of resources of the functional areas: financial, manufacturing, marketing, technological, manpower, innovative etc. in the pursuit of its objectives. The paper is based on primary and secondary research. One of the objectives of the primary research was to analyze and evaluate which performance drivers had impact on the strategic management in the years 2010 - 2012. On the basis of the questionnaire survey it was possible to point out the areas that can have a high impact on the competitiveness of organization. The analysis and classification of these areas is object of this paper. The aim of the paper is also to summarize basic relations among the areas, to deduce partial findings and to formulate some recommendations for entrepreneurial subjects.
\end{abstract}

Keywords: competitiveness, innovation, performance, strategic management.

JEL classification: L10, L21, M10

Doručeno redakci: 31.7.2014; Recenzováno: 5.8.2014; 11.8.2014; Schváleno k publikování: 23.9.2014

\section{Introduction}

Strategic management is a relatively youthful discipline that has steadily matured over the past fifty years. The field has become consolidated over this period, while simultaneously expanding the range of topics analyzed and research methodologies used. Different theories and approaches, addressing different research topics, have been developed to explain the reasons underlying firms' competitive advantage and success. In this paper, we posit the existence of two pendulums in constant motion that, on the one hand, reflect the tension that has historically existed between the focus on internal firm factors and external environmental attributes respectively and, on the other hand, the tension between a more macro level of analysis, i.e., the firm and its environment, and a more micro level one, i.e., individuals and their relations within the firm. The frontier of research in strategic management is shaped by the simultaneous movement of both pendulums.

Today's business world is much complex and has uncertain conditions which influence the companies to create effective strategies for the dynamic market. According to Hunger and Wheelen (2011) strategic management has now evolved to such a point that its primary value has evolved to help the organization to operate successfully in competitive environment.

According to Blažek (2007, p. 15) competitiveness of a company perceived as an economic success on a pre-defined market that is kontingent on internal and external factors within the enterprise and that is reflected in the performance of the business. Beneš (2006, p. 12) combines competitiveness of the company with the ability to bendit from a good image. It allows businesses through the bood brand to succeed better not only on the output market, but 
also in the means of market demand for employees, finacial market and market of components.

According to Aracioğlu, Zalluhoğlu, Candemir (2013) considering these complicated conditions and processes, performance measurement has become a popular concept in strategic management and it is important to know according to Rylková, Antonová (2013) that management of business development is associated with four components, which is necessary to support, implement and improve. These are:

- A management folder - applicable authorities of the founding documents of the companies (General Meeting, Board), including classic and flexible organizational structure.

- An executive folder - the component responsible for ensuring and innovative activities.

- An initiation folder (development) and coordination, in which companies shape complementary management structure (local action group, working groups on projects, etc.), which are actually implemented steps leading to the development of enterprises (manager of changes, advisors, external consulting firm).

- A strategic folder, which is a structure of a broader cooperation of various entities and individuals with long-term planning and implementation of innovative activities, corporate innovation projects (entrepreneurs, customers, suppliers, schools, regions).

The paper points out the contribution of factors, which have a significant impact on the competitiveness and development of companies and especially on strategic management.

\section{Theoretichal Framework Regarding Strategic Management}

Dinçer (2003, p. 35) generally defines strategic management as the whole set of decisions and activities for developing and implementing effective strategies and assessing and controlling them. Strategy is determining the goals and purposes of the organization and rearranging the necessary activities to realize these goals by analyzing the relationships between the organization and its environment and allocating the sources needed in a way that they will be effective in the long run.

Strategic management consists of research, review, assessment and selection efforts required for planning strategies, putting into action any kind of precautions within the organization in order for these strategies to be implemented and all activities related with controlling the works performed according to Thompson and Strickland (2003). Strategy is the whole set of activities that emerges as a result of rational planning according to David (2009, p. 36). Strategies can usually be interpreted as a set of hypotheses of causes and effects according to Norton and Kaplan (2005). Benefits from a strategy are listed as follow according to David (2009, p. 47):

- It ensures organization's adaptation to the environment and thus its long term survival.

- It makes it possible to assess the environment and estimate future.

- It creates the opportunitiy for a self-assessment for the organization.

- It enables direction towards a common goal as a whole within the organization and also consistency.

- It leads activities to a certain direction and forms a framework for plans.

- It increases management performance.

- It minimizes the risks to take decisions that will be regretted.

Several analysis techniques were developed within the framework of strategic management. Some of main techniques can be listed as the SWOT analysis, the BCG matrix, the experience 
curve, the scenario analysis, the gap analysis, the industry life curve, the corporate report and the quality function curve. These analysis techniques are often used today.

\section{Methodology}

Strategic management has gained importance in recent years due to significant contributions to company success. Department of Management and Business Administration of the Silesian University in Opava, School of Business Administration in Karvina carried out research entitled "Adaptability of enterprises (SMEs) in the years 2010-2012".

The primary objective of the research was to examine the impact of the economic situation in period 2010 - 2012 on the strategic management of companies in the Czech Republic on the basis of the potential correlation among questions.

The questionnaire survey was done in the summer term of 2013 by students of the Silesian University in Opava, the School of Business Administration in Karviná. About 400 respondents were approached; and filtering them produced 320 questionnaires duly filled and usable for the purpose of this survey. Polling took place throughout the Czech Republic, mainly in small and medium-sized enterprises. Respondents' selection was random.

The selected sample are 320 respondents within the Czech Republic. The ratio of small, medium, large-sized enterprises is 203:96:21. The criterion was the average staff size over the past three years.

The questionnaire form relied largely on closed-ended questions with an option to specify the answer in more detail. The questionnaire was split into these topic sections:

- Strategic company management

- Economic trends within company, crisis/risk management

- Company policy for human resources

- Production, services and innovative activity

- Research activities and cooperation

- Business performance measurement

- Company priorities in terms of sustainable economy

The data of questionnaire were subsequently entered into Microsoft Office 2007 Excel application for assessment. In order to evaluate the survey there was used the SPSS program. Outputs were achieved with using several methods, for the purposes of this study there were selected three methods: the Rotated Component Matrix (factor loadings after rotation, arranged by size), the Communalities (part of variability explained by variables common factors) and the Correlation Matrix (mutual dependence of two questions).

One of the objectives of the research carried out by the Department of Management and Business Administration was to analyze and evaluate which factors had an impact on the success of organizations and strategic management in the years $2010-2012$.

From the questionnaire survey conducted by the Department of Management and Business Administration it was possible to point out the areas that can have a high impact on the success of organization and strategic management.

Using the SPSS program there was found the structure of questions which join the links with other questions and are most responsible for the results that came out after the evaluation of 
the specified number (sample) of questionnaires. Questions correlation coefficient higher than 0.5 was found 19 times in the research of years 2010 - 2012, but in order to keep the contribution clear and concise, the table number 1 involved just 5 of the most important issues with a correlation coefficient higher than 0.8 .

In the primary research of the period 2010 - 2012 there was determined the following hypothesis: H1: Performance measurement is one of the factors affecting strategic management.

Out of the primary research the most important issues with a correlation coefficient higher than 0,8 are customer focused innovation, technology, brand, reach, reputation, collaboration with employees, strong business principles and sustainable development and performance measurement. Recognition of the potential importance of intangible performance drivers is in the table 1 .

Table 1: The most important questions - TOP 5 (Communalities), years 2010 - 2012

\begin{tabular}{|ll|c|r|}
\hline & Initial & Extraction \\
\hline 1. & Customer focused innovation (E2) & 1,000 & 0,872 \\
\hline 2. & Technology, brand, reach, reputation (C6) & 1,000 & 0,865 \\
\hline 3. & Collaboration with employees (C7) & 1,000 & 0,814 \\
\hline 4. & $\begin{array}{l}\text { Strong business principles and sustainable } \\
\text { development (E4) }\end{array}$ & 1,000 & 0,811 \\
\hline 5. Performance measurement (E3) & 1,000 & 0,806 \\
\hline
\end{tabular}

Source: own

Table 1 shows that customer focused innovation, technology, brand, reach, reputation, collaboration with employees, strong business principles and sustainable development, performance measurement are the categories which have a significant impact on strategic management (there was used an own evaluation by the SPSS). From the above, it is possible to confirm the hypothesis H1: Performance measurement is one of the factors affecting strategic management.

Based on the results of primary research from the years 2010 - 2012 it was possible to create a model of factors affecting strategic management (see Figure 1).

Figure1: Performance drivers for strategic management

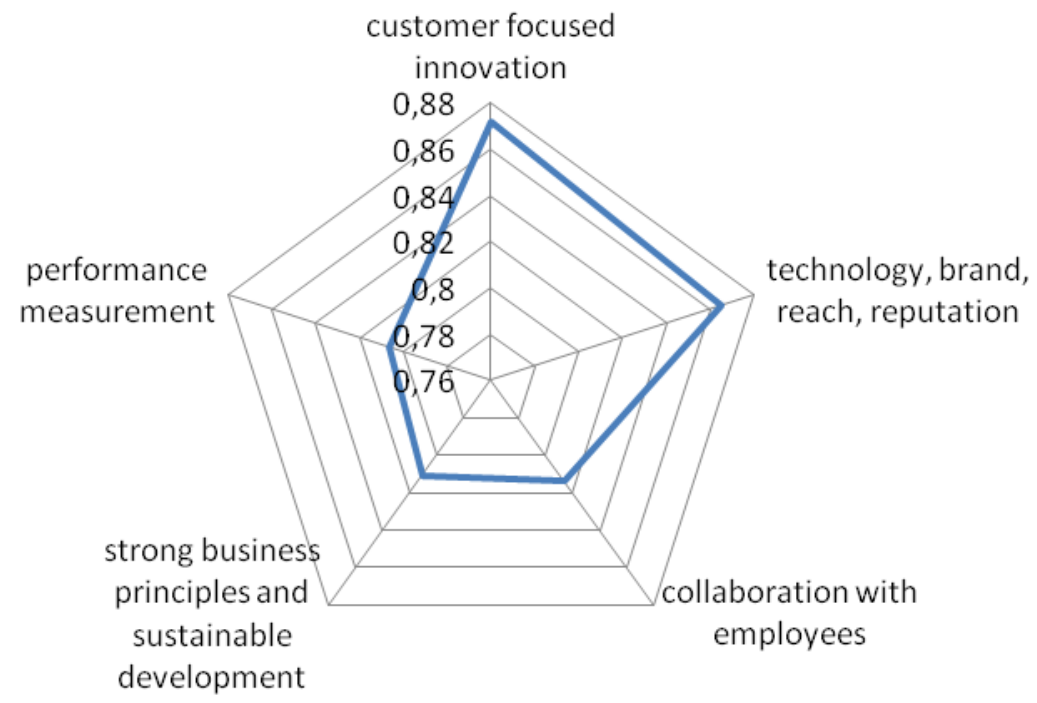

Source: own 
One of the objectives of the paper is the analysis and evaluation of factors that affect the strategic management based on the primary research.

\section{Customer Focused Innovation}

In successful product innovations, customers are significantly more deeply involved in the innovation process compared to less successful product innovation. $79 \%$ of asked companies have customer focused innovation. On the one hand, customers are - besides management and sales - the most important source for new innovative ideas. Collaboration with customers in the innovation process usually does improve the competitive situation of the company. Additionally, it reduces the risk that the new service will not find market acceptance. This approach may also avoid image loss, which would present a danger by a lack of market and customer orientation. In the early phases of the innovation process considerable time savings may be achieved by integrating customers, because potential research areas for fading new ideas will be identified better from the very beginning. Later on in the innovation process in the phases of conceptualization and implementation, collaboration with customers may positively affect development speed.

Nonetheless, especially customers who are actively and creatively expanding the use of a service beyond the current paradigma are motivated to participace in developing an innovation and therefore suitable from the company's perspective. All these atributs fit to lead users, who are especially qualified and motivated customers who may recognize future trends earlier and may provide innovation-relevant information according to Busse (2005). The question is therefore how to include feedback from customers into the process while limiting the obvious challenges that an increased collaboration across company boundaries poses according to Schulteß and Wegener and Neus and Satzger (2010).

\section{Technology, Brand, Reach, Reputation}

Technological activities increase the probability of a new product success. Such technological activities may be associated with the collection of technological knowledge, flexible development, the internal testing model (associated with research and development) and with the organization of technological process.

There is used the term "research and development" for technological activities but in many organizations the department exactly with that name does not exist. In small companies, these activities take place within the department, for example under the title "Technical Support" or "Construction". The location of research and development should take into account the physical location and their financing. Unlike large companies, where we usually find own research and development for monitoring and assimilation new technical knowledge, small firms study branch and technical publications, they are carry out training, they use consulting services, consulting, customers and suppliers. From our reserach - 172 organizations within 203 small organizations don't have department for technological activities, within 96 medium-sized organizations just 23 organizations have department for technological activities and within larg organizations from 21 organizations - 17 organizations have department for technological activities.

Brand can be defined as ,a distinctive name or symbol intended to identify the goods as belonging to a certain producer and to differentiate them from the competition. Like any other asset, brand management is very important for the success of the company in the market. According to Olins (2009) if launched and supported effectively, the bran dis a major corporate resource - sometimes the most valuable financial asset of an organization. The 
brand, as finance, investment, human resources, research and development, marketing, information technology and other corporate resources, needs authority, rules, proper funding, commitment and management.

Reputation has always been perceived as an important factor in business and the accounting had been using for hundreds of years the term of goodwill to designate added value that cannot be attributed to tangible assets and which is included as an amorphous mass of intangible assets. In the second half of the last century, mergers and capital market development (through transactions at values higher than tangible assets) have shown that a business should be evaluated beyond its tangible assets (,factories") and that intangible assets can generate a great value to a company. The brand has stood out in recent decades as a massive generator of value in many industries and thus the identification has become necessary and also its „exclusion“ from goodwill range (including as wll patents, copyrights, know-how, and so on). The bran is sometimes called ,hidden value“ because in most cases it does not appear in the financial statements of companies.

\section{Collaboration with Employees}

Organizational structure in SMEs tends to cycle on flat organizational structure, but there is a great danger of overloading of the top management, which in this case is an entrepreneur or an executive manager.

In organizations it is very important to evaluate opportunities to transmit innovative ideas and views, if there is space and scope to develop innovative ideas, if there is support for innovative ideas in the business, whether it is admited the truth (and unpleasant) and whether it is adequately perceived. It is important to develop a description of key employees of the company and in what way they should be developed. It is important to build internal consistency among all stakeholders in the organization with the general acceptance of instrumental values that are associated with achieving innovation success. It is important to open the floodgates to creative potential of all staff in the effective involvement in innovative activities of the company. The entrepreneur should choose such a management style that suits both him or her and their staff and there should be the benefits to the whole organization.

In order to capture the level of employee initiative with regard to innovation in products, we used in the questionnaire the scale (Level 1 - Level 5)

- Level 1: employees will not become active until their manager demands this (13\% of asked).

- Level 2: employees ask their manager actively for possibilities to take part (20\% of asked).

- Level 3: employees suggest actions to their responsible manager and, then if approved, carry out the agreed actions (36\% of asked).

- Level 4: employees conduct activities on their own but report to their manager immediately ( $22 \%$ of asked).

- Level 5: employees conduct self dependent acitivities and report to their responsible manager intermittently ( $9 \%$ of asked).

Additionally, a corporate culture that provides the space for employees to actively participate in the innovation process - including explicitly condoning employee initiative and allowing for some risk and experimentation - also has shown a clear positive impact on the success and innovation of a company. According to Schulteß and Wegener and Neus and Satzger (2010) those companies whose employees showed a high level of self dependent initiative - 
supported by the company - show higher revenue growth and higher share of new product revenue.

Figure 2 shows the breakdown of organisational assets into physical, financial, and intangible assets.

Figure 2: Organisational Assets

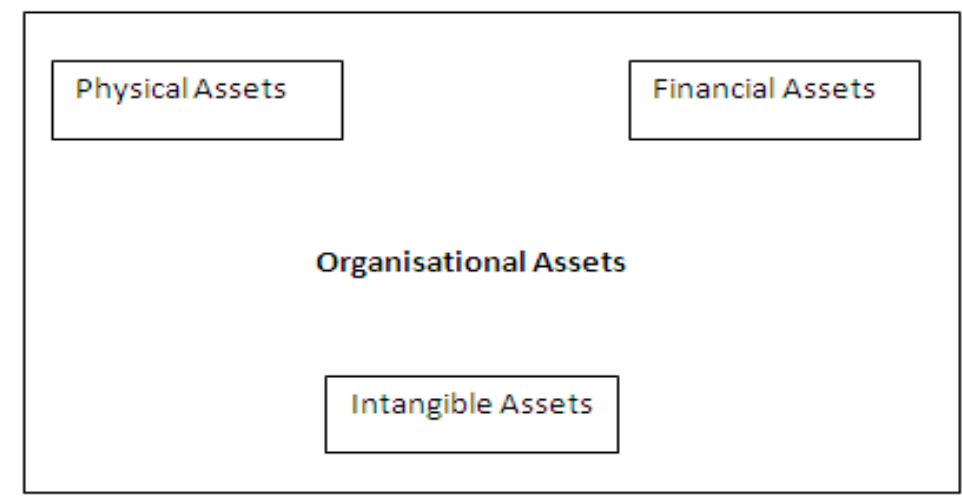

Source: own

We can say that collaboration with employees can be involved into ingangible assets. Intangible assets are then subdivided into human, relations, and structural assets.

For the purpose of this paper, intangible assets are defined as those key value drivers that do not have a physical presence and are based on intelligence or emotions. They may be analysed as:

- Human assets: skills, competence, commitment, motivation, loyalty of employees, technical expertise, problem-solving capabilities, creativity, education, attitude, entrepreneurial spirit.

- Relationship assets: relationships with stakeholders, licensing agreements, partnering agreements, contracts, distribution arrangements, customer loyalty, brand image.

- Structural assets: all intangibles that stay with the organization - corporate culture, routines and practices, virtual networks, tacit rules, intellectual property - patents, copyrights, trademarks, brands, registered designs, trade secrets and processes whose ownership is granted by law.

Human assets, relationship assets and structural assets (intangible assets) should be involved into the term organizational learning. We define organizational learning as the organizational process aimed at adding value to the knowledge acquired and communicated throughout the firm. As such, organizational learning process encompasses the acceptance and the assimilation of knowledge. We can say that organizational learning is the process that should lead to the firm's competencies development and a valuable learning experience will lead to firm-specific, distinctive competencies.

In addition, organisations have to understand their corporate competence and resource composition in order to evaluate these opportunities. Different firms develop different distinctive competencies and the question they have to ask themselves is: do we have the right competence to pursue certain opportunities? 
As for competency model for sharing knowledge Rylková and Šebestová (2011) have suggested their own $5 \mathrm{C}$ modell with these components:

- Clarification of relationship - establishment of organisational structure,

- Communication - effective communication within organisational structure,

- Care - development of "database of knowledge", shared by employees,

- Culture - organizational learning, market of ideas within organization, time and space for innovation, open space for communication),

- Competitiveness - clarification of relationship, communicaton, care and culture should bring a synergy effect and innovation and innovation for organization.

\section{Strong Business Principles and Sustainable Development}

We would like to stress Bartošek et al. (2013) who noted that strong business principles requires a whole collaborative partner approach, which evolves and adapts all requirements to meet dynamic environment and also partner's needs.

According to Rylková (2013) enterprises have to realize that they are surrounded with an external envirnoment that supports or does not support development. The company itself uses inputs that transforms into outputs, provides products or services and solve problems such as where to obtain information, resources, customers, qualified staff, how to develop the company. The behavior of the company influences the market. Influence of the market is becoming difficult, so it is necessary for the company to seek new forms of development and to establish new forms of cooperation. The innovation process is nowadays without intensive cooperation with $\mathrm{R} \& \mathrm{D}$ organizations, universities and other innovative parts of the region (also known as an innovative process of „higher rank“.). This cooperation, which is still not so used in the Czech Republic yet, is one of the characteristics of the knowledge economy and it is a source of competitiveness of firms and regions. From our reserach just $32 \%$ of selected sample cooperate with external organizations on innovation. Most of today's successful innovations are a combination of innovations, where combined products are the outputs of joint innovation activities carried out by individual members of networks. The linear model of innovation is being replaced with an interactive model. All of these areas should be included in the development strategy, which will also include prerequisites for innovation and lead to innovation effect. The innovation effect should include measurable results, balanced cost of capital, it should include both qualitative and quantitative criteria, it is necessary to monitor the market position and create and develop a corporate culture which is opened to innovation. All above mentioned is very important to analyze for sustainable development of organization.

Thery is also very important development strategy. Development strategy in written form have just $37 \%$ of selected sample. Its objective could be to increase sales and margins through developing and selling environmentally and socially friendly product innovations. It is also important to measure the effect of the development strategy.

\section{Performance Measurement}

Strategic management involves setting goals for organizations and aims to increase profitability and efficiency to achieve these goals by using performance management systems. For the secondary research of performance measurement there was chosen the research project of the Czech Association for Financial Management (2011) under the title "Development of a model for measuring and managing business performance", which was supported by the Grant Agency of the Czech Republic. Research was attended by 402 companies from the Czech Republic and the research period was the year 2010. In terms of 
the distribution of the respondents there were $27 \%$ of large enterprises, $36 \%$ of medium-sized companies, $27 \%$ of small businesses and $10 \%$ were micro enterprises. Half of the respondents were focused on manufacturing activity, $30 \%$ of enterprises on services and $20 \%$ were commercial enterprises. Enterprises in the survey indicated that relevant reasons why to implement a system of performance measurement and management in the company are numerous. Strategic planning, controlling and motivating and rewarding are considered to be the most important.

$73 \%$ of companies indicated that performance measurement was based on the strategy and objectives of the company and helped in their development. $7 \%$ of businesses reported that performance measurement is not based on strategies and goals which had been formulated. $20 \%$ of companies said that the strategy and goals are not formulated. Performance measurement is performed in specific activities and processes.

Companies consider finance as the most important area of performance management. The following is the area of customer, employees, internal processes, innovation, health and safety and the use of IS / ICT.

The most frequently used financial indicator is sales, it uses about $75 \%$ of the companies. Other important benchmarks include return on sales figures of net profit, profit before tax, using cash flow indicators or cost-effectiveness. Average used financial performance indicators are added value, ROE, ROA, ROI, EBIT, it uses at least one third of asked businesses.

Another frequently used tool of control and performance measurement besides financial indicators is controlling, which is used by more than $75 \%$ of enterprises of the Czech Republic, an important indicator is also managerial accounting, which uses almost $70 \%$ of businesses. Other concepts and tools are used by less than $50 \%$ of enterprises. The firms are also most satisfied with above mentioned tools, while methods such as EVA and Balanced Scorecard used far fewer businesses. A survey conducted in 2005 shows that EVA used only about $40 \%$ of the surveyed firms on the Czech market. New survey from 2010 already shows only $30 \%$, which is quite surprising finding given that nearly $80 \%$ of companies surveyed in 2005 reported that EVA is deemed suitable for enterprise performance management.

The Balanced Scorecard method used even less than $20 \%$ of companies. The specific reason for small representation of companies which use new complex systems such as the Balanced Scorecard is the fact that this model was originally designed for large enterprises, while in the Czech Republic there dominate small businesses or medium-sized businesses.

From the questionnaire entitled "Adaptability of enterprises (SMEs) in the years 2010-2012" it was selected the sample of 130 respondents. On the question which method is used to performance management - $12 \%$ of enterprises stated the TQM method, $2 \%$ of respondents stated the EFQM method, the ISO 9000 uses $17 \%$, the six sigma $5 \%$, the MBO method uses $2 \%$, the BSC method uses $4 \%$, the SMART uses $9 \%$, the BCG uses $3 \%$, the SWOT uses 22 $\%$ the PESTLE $1 \%$ and $23 \%$ of respondents stated that they use other methods (Kaizen, $\mathrm{ABC})$.

Regarding the characteristics of the performance measurement system in the enterprise, from the sample of 130 companies stated $40 \%$ of companies stated that they had established the performance measurement system and they use it. $8 \%$ of companies stated that they had 
assembled the performance measurement system, but they do not use it, $14 \%$ of businesses reported that a performance measurement system was in the phase of making or implementation and the remaining $38 \%$ reported that they did not measure performance.

In the answer to the question which system of performance measurement companies use -46 $\%$ stated that they use financial ratios, $27 \%$ use comparison with plan, $10 \%$ use the system using standards, the BSC was used by $4 \%$ of companies, $6 \%$ stated that they use the TQM, $6 \%$ stated that they use other performance measurement systems (there were recorded responses such as the KPI, or none).

In the question about the indicators companies use to measure performance stated $58 \%$ of companies stated that they use just financial indicators, $5 \%$ stated that they use just nonfinancial indicators and $37 \%$ of companies stated that they use, both financial and nonfinancial indicators to measure business performance.

The ways and means of measuring performance are perceived as being an increasingly important field of research for both companies and academics. Since the early 1990s, companies have invested increasing amounts of money and other resources to measure their performances. As stated in Folan and Browne's study, many of the most popular recommendations concerning performance measures date from the late eighties and early nineties when performance measurement as a concept was being formed. According to the studies of Folan and Browne (2005) performance measurement should:

- Be kept physical (i.e. quantitative)

- Be taken as close to the customer as possible

- Have top management support

- Involve employees in their development (particularly customer satisfaction measurement)

- Ensure that those measures used are relevant to managers and employees in performing their day-to-day workload

- Be part of a feedback loop that links them to manager and employee performance appraisals

- Primarily use non-financial performance techniques

- Vary between locations

- Change over time as the company needs change

- Be interested to foster improvement rather than just monitoring

\section{Conclusion}

Strategic management is a key source of competitive advantage, especially in today's highly dynamic, competitive environment, the economic success is highly dependent primarily on the enterprise's ability to successful development and implementation of innovations. To ensure that strategic management has been successful, it is necessary to pay attention to a variety of factors, those conditions positively and negatively can affect the organization. Based on the secondary and the primary research the paper highlights the factors that need to be monitored and developed if companies want to be successful.

In terms of sustainable competitiveness there is important continuous development of strategic management in companies. Strategic management of firms affects a group of different factors. There are factors associated with the business environment - such as economical, social, cultural, demographic, environmental, legal, cooperation with other 
organisations, innovative ideas and trends, and modern innovative approaches. In addition, there are factors associated with the personality of a manager and employees (a personal approach) - where knowledge workers and managers and their experience make the development of company. Another group consists of factors associated with organizations (access to resources) - resources owned organizations depend on characteristics of organizations (organization size, legal form of business, age of organization). The last group of factors is associated with the strategy and with the way of managing an organization (a strategic approach) - it has to be remembered that the chosen method of managing organization can become difficult to reproduce the cause of competitive advantage and it is also important to measure the performance for organization in order to be competitive.

From the primary research of the period 2010 - 2012 there were found categories which have a significant impact on strategic management of businesses to respond to changes and development. It was found out that, customer focused innovation, technology, brand, reach, reputation, collaboration with employees, strong business principles and sustainable development and performance measurement where the categories which should be managed and could have the greatest impact on strategic management of companies to changes and development.

Based on the results of primary research from the years 2010 - 2012 it was possible to create a model of factors affecting strategic management. This model „Performance drivers for strategic management" should not be the final goal itself for organisations. This model should be understood as the effective tool for strategic management. In the future, there will be studied the impact of individual components of the model in terms of sectors and in terms of company size.

\section{References}

[1] ARACIOĞLU, B., A. E. ZALLUHOĞLU and C. CANDEMIR, 2013. Measuring and Evaluating Performance within the Strategic Management Perspective: A Study on Performance Measurement of A Seafood Company. Procedia - Social and Behavioral Sciences [online]. 99(1), 1026-1034. [cit. 6th July 2014]. ISSN 1877-0428. Accessible from: http://www.sciencedirect.com/science/article/pii/S1877042813040214

[2] BARTOŠEK, V. and E. TOMÁŠKOVÁ, 2013. Interfunctional Coordination from Company Functions Point of View. Acta academica karviniensia, 13(3), 5-18. ISSN 1212-415X.

[3] BENEŠ, M., 2006. Konkurenceschopnost a konkurenční výhoda. Centrum výzkumu konkurenční schopnosti České republiky. Working paper 5/2006. ISSN 1801-4496.

[4] BLAŽEK, L., 2007. Konkurenční schopnost podniki̊. Brno: Masarykova univerzita. ISBN 978-8021-044-562.

[5] BUSSE, D., 2005. Innovationsmanagement industrieller Dienstleistungen - Theoretische Grundlagen und praktische Gestaltungsmöglichkeiten. 1st ed. Wiesbaden: Deutsche Universitätsverlag/GWV Fachverlage GmbH. ISBN 38-3500-120-5.

[6] Czech Association for Financial Management, 2011. Tvorba modelu pro měrení a řízení výkonnosti podniků. Dotazník Měření a řízení výkonnosti podniků - závěrečná zpráva [online]. [cit. 14th July 2013] Accessible from: http://www.cafin.cz/sites/default/files/Zprava.pdf. 
[7] DAVID, F. R., 2009. Strategic management: Concepts and Cases. 12th ed. Florida: Prentice Hall. ISBN 978-0136015703.

[8] DINÇER, Ö., 2003. Structuring strategic management with ratio analysis method: a case study in the transitiv to SME TFRS process. In: A. HALICI and D. U. ERHAN, eds. Procedia - Social and Behavioral Sciences [online]. 99(1), 947-955 [cit. 22 nd July 2014]. ISSN 1877-0428. Accessible from: http://www.sciencedirect.com/ science/article/pii/S1877042813040135

[9] FOLAN, P. and J. BROWNE, 2005. A Review of Performance Measurement: Towards Performance Management. Computers in Industry, 56(1), 663-680. ISSN 0166-3615.

[10] HUNGER, J. D. and T. L. WHEELEN, 2011. Essentials of Strategic Management. Florida: Prentice Hall. ISBN 978-0136-006-695.

[11] KAPLAN, R. S. and D. P. NORTON, 2005. Balanced scorecard. Strategický systém měreni výkonnosti podniku. Praha: Management Press. ISBN 80-7261-124-0.

[12] OLINS, W., 2009. The Brand Handbook. 1st ed. London: Thames and Hudson Ltd. ISBN 978-0500-514-085.

[13] RYLKOVÁ, Ž. and B. ANTONOVÁ, 2013. Impact of Different Factors on the Success of Organization. In: Vision 2020 Innovation, Development Sustainability, and Economic Growth. Vídeň: Khalid S. Soliman, s. 1404-1412. ISBN 978-0-9860419-0-7.

[14] RYLKOVÁ, Ž., 2013. Innovative Business and the Czech Republic. In: Proceedings of the 11th International Conference Liberec Economic Forum 2013. Liberec: Technical University of Liberec, s. 485-495. ISBN 978-80-7372-953-0.

[15] RYLKOVÁ, Ž. and J. ŠEBESTOVÁ, 2011. Competencies and Innovation within Learning Organization. In: The Journal Economics and Management (EBSCO). Kanaus, Lithuania, s. 954-960. ISSN 1822-6515.

[16] SCHULTEß, P., S. WEGENER, A. NEUS and G. SATZGER, 2010. Innovating for and with your service customers: An assessment of the current practice of collaborative service innovation in Germany. Procedia Social and Behavioral Sciences [online]. 10(2), 6503-6515 [cit. 21st July 2014]. ISSN 1877-0428. Accessible from: http://www.sciencedirect.com/science/article/pii/S1877042810011183

[17] THOMSON, A. A. and A. J. STRICKLAND, 2003. Strategic Management Concepts and Cases. 13th ed. New York: McGraw-Hill. ISBN 978-00-7249-395-5. 